\title{
Structure and Determinants of Intra-Industry Trade in Agro -Food Sector of Bosnia and Herzegovina
}

\author{
Vesna Mrdalj \\ Aleksandar Ostojić \\ Željko Vaško,Dragan Brković \\ University of Banja Luka, Faculty of Agriculture, \\ Bosnia and Herzegovina
}

\begin{abstract}
This paper aims to contribute to a better understanding of the structure and determinants of intra -industry trade specialization in agro food sector of Bosnia and Herzegovina over the transition period. The empirical analysis based on calculation of the following indicators: Grubel - Lloyd index (GL), Revealed Comparative Advantages (RCA indicator) and Relative unit value (RUV indicator). In order to show the level of intra-industry trade specialisation and to examine comparative advantages at sectoral level, as well for individual product group, are calculated Grubel - Lloyd index and RCA indicator. RUV indicator is used for analysis of two components of total intra-industry trade (TIIT); horizontal intra - industry trade (HIIT) and vertical intra- industry trade (VIIT) of agro-food products in Bosnia and Hercegovina. The analysis and calculations of above mentioned indicators are conducted using the data about international trade of agro-food products in Bosnia and Hercegovina for period of time 2008-2015, as well data at 4 - digit level, classified according to HS (Harmonised System). The final analysis in this paper is finished through applying $K$ - means cluster analysis. $K$ - means method was used for identificiation of different clusters of agricultural and food commodity groups related to comparative advantages, level of specialization in intra - industry trade, as well as the ratio between unit value export and unit value import. The emprical results indicated that $\mathrm{GL}$ index for observed period at sectoral level is lower than $50 \%$. The values of RCA indicator for agro-food sector of Bosnia and Herzegovina in international trade and to important trade markets indicate lack of comaparative advantages. In the structure of intra - industry trade is dominated vertical specialization.
\end{abstract}

Keywords: intra-industry trade, vertical and horizontal specialization, agri-food products, comparative advantages, Bosnia and Herzegovina

\section{Introduction}

Bosnia and Herzegovina, throughout the adoption and application of certain trade agreements; 32 bilateral trade agreements, which are later integrated in one unique mulilateral trade agreement - CEFTA, and the Stabilisation and Association Agreement (SAA) with EU, affected the active involvement of agro - food sector into integrations processes. CEFTA agreement between Bosnia and Herzegovina and Western Balkan countries, came into force in 2007 and SAA in June 2015. Through the signing of SAA agreement, were created the conditions for submitting of application of Bosnia and Herzegovina for EU membership and obtaining of candidate status country. Thanks to CEFTA and SAA agreement (especially trade component of SAA - interim trade agreement), it is enabled the trade in agricultural and food commodities between Bosnia and Herzegovina and CEFTA - EU countries. These groups of countries are considering as two most important trade partners or destination markets in agricultural and food products of Bosnia and Herzegovina. Generally, Bosnia and Herzegovina has an unfavourable trade balance of agricultural and food commodities. The proportion of agro food sector of total country exports amounted an average about 7.9\%. Agro-food sector of Bosnia and Herzegovina is contributed to $17.9 \%$ of the value of total imports (average for period of time 2008-2015). There are many reasons for the unfavorable trade balance of Bosnia and Herzegovina's agro - food sector. According to Bajramović, Ognjenović, Nikolić 
(2010), differences between Bosnia and Herzegovina and EU standards and legislation, an insufficiently recovered and undeveloped food industry, week of support for domestic production, low level of market - oriented production for founding critical mass necessary for export, as well as problems with qaulity and high expenditures for the collection of products, slow structural reforms in agriculture, not enough attention to direct foreign investments that could bring fresh capital, new technologies, products and markets, contribute to this situation. In order to better integration and achievement of competitiveness in international trade, it is important to build a market and export - oriented agro - food sector.

How much is competitive agro - food sector of Bosnia and Herzegovina and what is its position in international trade of transition period ? In order to obtain the answers on this question, in this paper are analysed comparative advantages and the level of specialization of intra - industry trade. This question is very important, considering the role and significance of intra - industry trade in the process of globalization and integration of transition economies on international markets (Buturac, 2006). The reasearch in this field are leaded by Aturpane, Djankov, and Hoekman (1997), which showed that intra- industry is the fastest growing segment in the international trade of transition economies. Intra -industry trade is defined as simultaneous export and import of commodities of the same industry (Vollrath, 1991). Intra - industry trade can be horizontal (HIIT), which means export and import of products with approximately the same level of quality. The second components of intra - industry trade is vertical (VIIT), whereby in trade are products with different quality. Theoretical basis for horizonatal intra - industry trade are developed by Lancaster (1980), Krugman (1981), Helpman (1987) and Bergstrand (1990). These models implie that as countries are similar in terms of their income, is the greater share of horizontal intraindustry trade. On the other hand, theoretical basis for vertical type of intra - industry trade has developed Falvey (1981). Falvey suggest that since higher - value added products require higher - capital intensity in production, in an open economy the capital - rich country will export high - quality products wheres the labor - rich country will export low - quality products.

The purpose of this paper is to contribute to a better understanding of the structure of intra -industry trade specialization in agro - food sector of Bosnia and Herzegovina over the transition period, precisely to identify which component of intra industry is dominant. The paper is diveded into five parts: introduction, methodology, results, conclusion and references. The results in the paper are divided into two parts; in the first part are represented data on agro - food trade development in Bosnia and Herzegovina 2008 - 2015, and in the second the results by applying of RCA indicator, GL index and RUV indicator.

\section{Methodology}

The empirical analysis in this paper based on using following indicators:

1) Revealed Comparative Advantages (RCA)

2) Grubel - Lloyd Index ( $\left.G L_{i}\right)$

3) Relative Unit Value ( RUV indicator)

RCA indicator is used to analyse comparative advantages of agro-food sector of Bosnia and Herzegovina.The indicator is originally developed by Bela Balassa (1965) and is calculated according to following formula:

$\left.\mathrm{RCA}=\ln \left[\frac{X_{i}}{M_{i}}\right]\right]^{*}\left[\frac{\sum_{i=1}^{n} X_{i}}{\sum_{i=1}^{n} M_{i}}\right]^{*} 100$

whereby $X$ is definition for value of export and $M$ for value of imports. Index $i$ presents production group classified according to Harmonised System (01-24), referred in total trade for period 2008-2015. The interpretation of this indicator is the following; a postive value indicates that the country has compartive advantages in production and trade of given sector and corresponding product group. Negative value of RCA indicator implies a lack of comparative advantages. The indicator is calculated for agro-food sector of Bosnia and Herzegovina in total trade, as well in trade between Bosnia and Herzegovina and main trade partners (CEFTA and EU countries). For the analysis of the level of intra-industry trade specialization of agro-food sector Bosnia and Herzegovina is used aggregate Grubel-Lloyd's index, calculated using the formula:

$\mathrm{GL}_{\mathrm{i}}=1-\frac{|x-m|}{x+m}$

whereby $\mathrm{GL}_{i}$ is the value of the Grubel-Lloyd index for sector $i, X$ stands for value of export and $M$ is the value of import. For individual products group the $\mathrm{GL}$ index is calculated by formula: 
$\mathrm{GL}_{i}=\frac{\sum_{i=1}^{\mathrm{n}}\left(\mathrm{X}_{\mathrm{i}}+\mathrm{M}_{\mathrm{i}}\right)-\sum_{i=1}^{\mathrm{n}}\left|\mathrm{X}_{\mathrm{i}}-\mathrm{M}_{\mathrm{i}}\right|}{\sum_{\mathrm{i}=1}^{\mathrm{n}}\left(\mathrm{X}_{\mathrm{i}}+\mathrm{M}_{\mathrm{i}}\right)} * 100$

whereby $\mathrm{GL}_{i}$ is the value of the Grubel - Lloyd index for product group $i . X$ is defined as the value of export and $M$ is the value of import. Overall, value of $\mathrm{GL}$ index ranges from 0 to 1. The interpretation of coefficient is; lower value of $\mathrm{GL}$ index implies higher degree of specialization in inter-industry trade. The value of GL index closer to 1 shows that country has a higher level of specialization in intra-industry trade. The GL index is calculated for agro-food sector in total trade, as well in trade between Bosnia and Herzegovina and main trade partners (CEFTA and EU). GL index is calculated for each individual product groups classified according to Harmonised System (01-24), related to total trade for period 2008-2015. The methodology for calculating of GL index is originally developed by Grubel and Lloyd (1975). The third indicator calculated in this paper was Relative Unit Value (RUV), used for analysis of horizontal and vertical intra-industry trade. The RUV indicator was first proposed by Abd-el-Rahman (1991), Greenway et.al. (1994), and then by Blanes, Martin (2000). RUV is based on ratio of unit value of export and import.

$1-\mathrm{a} \leq \frac{\mathrm{UVX} i}{\mathrm{UVM} i} \geq 1+\mathrm{a}$

UVX $X_{i}$ stands for unit value of export for product groups $i$ and is calculated as the value of export divided by the export quantity. UVMi refers to the unit value of import and is calculated as value of import divided by the import quantity. The parameter $\boldsymbol{\alpha}$ is coefficient of dispersion. The coefficient of dispersion $\boldsymbol{\alpha}$ is assumed to be equal 0.15 (Abd-el- Rahman 1991; Greenaway et al. 1995; Aturpane et al. 1999; Blanes et al. 2000; Algieri 2004; Reganati and Pittiglio 2005; Buturac 2006). If the ratio of unit value of export and import is whithin the interval $(0.85 ; 1.15)$ intra-industry trade is horizontal; converesely if the RUV is outside of this interval, intra-industry trade is vertical.If the RUV is greater than 1.15, the country is "exporting quality", while if it is smaller than 0.85 the country is "importing quality" (Buturac, 2006). Formally:

$I I T=H I I T+V I I T=H I I T+\left(V I I T^{L Q}+V I I T^{H Q}\right)$

$\mathrm{HIIT}=0.85<\frac{\mathrm{UVX} i}{\mathrm{UVM} i}<1.15$

$\mathrm{VIIT}=\frac{\mathrm{UVX} i}{\mathrm{UVM} i}<0.85$ for VIITLQ and $\frac{\mathrm{UVX} i}{\mathrm{UVM} i}>1.15$ for $\mathrm{VIIT} \mathrm{T}^{\mathrm{HQ}}$

In this paper, the calculation of RUV indicator is based on using of data for agricultural and food products at 4 - digit level, classified according to Harmonised System (01-24) and is analyzed for three years $(2008 ; 2011 ; 2015)$.

$K$ - means cluster analysis in the paper was used to determine different clusters of agicultural product groups related to comparative advantages, level of specialization of intra - industry trade and relative unit value. In $k$-means cluster analysis, as variables are used values of RCA indicator and GL index for period of time $2008-2015$. Product groups at the 4- digit level according to Harmonised System represented objects of clustering for 2008, 2011 and 2015.

\section{Results}

Results in this paper are divided in two parts. The first part represents the data on agro-food trade of Bosnia and Herzegovina for period of time 2000-2015. In the second part are represented empirical results obtained by calculations of RCA indicator, GL index and RUV indicator, as well as results by applying of $k$ - means cluster analysis.

\section{Agricultural trade - Bosnia and Herzegovina}

Bosnia and Herzegovina recorded constantly an unfavorable trade balance of agricultural and food commodities. Total volume of trade of the agricultural sector in period of time 2008 - 2015 amounted an average of EUR 1.681 billion, accouting for $14.5 \%$ of Bosnia and Herzegovina's total trade.

Table 1.Total trade and trade in agro-food products of Bosnia and Herzegovina 2008 - 2015.

\begin{tabular}{l|llllllll}
\hline BH total (mil.EUR) & 2008 & 2009 & 2010 & 2011 & 2012 & 2013 & 2014 & 2015 \\
\hline Export & 3.432 & 2.828 & 3.628 & 4.204 & 4.018 & 4.285 & 4.439 & 4.595 \\
Import & 8.330 & 6.317 & 6.962 & 7.938 & 7.799 & 7.757 & 8.283 & 8.105 \\
Total & 11.762 & 9.145 & 10.590 & 12.142 & 11.816 & 12.042 & 12.721 & 12.700
\end{tabular}




\begin{tabular}{l|llllllll} 
Trade Balance & -4.899 & -3.489 & -3.334 & -3.734 & -3.781 & -3.472 & -3.844 & -3.510 \\
\hline Coverage (\%) & 41.19 & 44.77 & 52.11 & 52.96 & 51.52 & 55.24 & 53.59 & 56.70 \\
\hline Agro-food BH total (mil.EUR) & & & & & & & & \\
\hline Export & 217 & 238 & 283 & 314 & 326 & 350 & 332 & 430 \\
Import & 1.320 & 1.210 & 1.279 & 1.416 & 1.440 & 1.421 & 1.407 & 1.464 \\
Total & 1.537 & 1.448 & 1.562 & 1.730 & 1.767 & 1.771 & 1.739 & 1.893 \\
Trade Balance & -1.103 & -972 & -997 & -1.103 & -1.114 & -1.070 & -1.075 & -1.034 \\
\hline Coverage (\%) & 16.45 & 19.69 & 22.10 & 22.14 & 22.65 & 24.66 & 23.58 & 29.35 \\
\hline Share of Agro-food in total BH & & & & & & & & \\
trade (\%) & & & & & & & & \\
\hline Export & 6.33 & 8.42 & 7.79 & 7.46 & 8.12 & 8.18 & 7.48 & 9.35 \\
Import & 15.84 & 19.15 & 18.38 & 17.84 & 18.47 & 18.31 & 16.99 & 18.06 \\
Total & 13.07 & 18.84 & 14.75 & 14.25 & 14.95 & 14.71 & 13.67 & 14.91 \\
\hline
\end{tabular}

Source: Agricultural Statistics Database - Bosnia and Herzegovina 2016; calculation of structure by authors.

Table 2. Total trade and trade in agro-food products between Bosnia and Herzegovina and CEFTA - EU countries 2008 2015.

\begin{tabular}{|c|c|c|c|c|c|c|c|c|}
\hline CEFTA total (mil. EUR) & 2008 & 2009 & 2010 & 2011 & 2012 & 2013 & 2014 & 2015 \\
\hline Export & 1.274 & 1.076 & 1.302 & 1.469 & 1.270 & 683 & 694 & 682 \\
\hline Import & 2.409 & 1.696 & 1.883 & 1.985 & 1.964 & 859 & 953 & 1.001 \\
\hline Total & 3.683 & 2.772 & 3.185 & 3.454 & 3.234 & 1.542 & 1.647 & 1.683 \\
\hline Coverage (\%) & 52.88 & 63.46 & 69.14 & 74.04 & 64.64 & 79.54 & 72.90 & 68.17 \\
\hline \multicolumn{9}{|l|}{ Agro-food sector } \\
\hline Export & 162 & 166 & 188 & 230 & 239 & 134 & 136 & 145 \\
\hline Import & 730 & 693 & 721 & 764 & 650 & 370 & 404 & 437 \\
\hline Total & 893 & 860 & 910 & 994 & 889 & 504 & 540 & 582 \\
\hline Trade Balance & -568 & -527 & -533 & -535 & -412 & -235 & -268 & -293 \\
\hline Coverage (\%) & 22.22 & 23.99 & 26.12 & 30.05 & 36.68 & 36.36 & 33.67 & 33.11 \\
\hline \multicolumn{9}{|l|}{ Structure (\%) } \\
\hline Export & 12.74 & 15.46 & 14.47 & 15.63 & 18.79 & 19.68 & 19.57 & 21.23 \\
\hline Import & 30.31 & 40.90 & 38.31 & 38.51 & 33.11 & 43.06 & 42.38 & 43.71 \\
\hline Total & 24.23 & 31.02 & 28.56 & 28.78 & 27.49 & 32.70 & 32.76 & 34.60 \\
\hline \multicolumn{9}{|l|}{ EU total ( mil.EUR) } \\
\hline Export & 1.893 & 1.534 & 1.979 & 2.345 & 2.328 & 3.156 & 3.204 & 3.299 \\
\hline Import & 3.996 & 3.100 & 3.196 & 3.602 & 3.660 & 4.658 & 4.880 & 4.932 \\
\hline Total & 5.889 & 4.635 & 5.175 & 5.948 & 5.988 & 7.814 & 8.084 & 8.231 \\
\hline Trade Balance & -2.102 & -1.566 & -1.218 & -1.257 & -1.332 & -1.502 & -1.676 & -1.633 \\
\hline Coverage (\%) & 47.39 & 49.49 & 61.90 & 65.10 & 63.60 & 67.75 & 65.66 & 66.89 \\
\hline \multicolumn{9}{|l|}{ Agro-food sector } \\
\hline Export & 46 & 56 & 74 & 111 & 105 & 173 & 126 & 126 \\
\hline Import & 491 & 426 & 466 & 476 & 440 & 787 & 792 & 811 \\
\hline Total & 537 & 482 & 540 & 586 & 544 & 960 & 917 & 937 \\
\hline Trade Balance & -445 & -370 & -392 & -365 & -335 & -614 & -666 & -686 \\
\hline Coverage (\%) & 9.36 & 13.16 & 15.87 & 23.26 & 23.84 & 21.93 & 15.86 & 15.52 \\
\hline \multicolumn{9}{|l|}{ Structure (\%) } \\
\hline Export & 2.43 & 3.65 & 3.74 & 4.72 & 4.50 & 5.47 & 3.92 & 3.82 \\
\hline Import & 12.28 & 13.73 & 14.57 & 13.20 & 12.01 & 16.90 & 16.23 & 16.45 \\
\hline Total & 9.11 & 10.39 & 10.43 & 9.86 & 9.09 & 12.28 & 11.35 & 11.39 \\
\hline
\end{tabular}

Source: Agricultural Statistics Database - Bosnia and Herzegovina 2016; calculation of structure by authors. 
Export of the agricultural sector represented an average of EUR 311 million, or $7.9 \%$ of total country's export. Agricultural imports were significantly higher, amountig to an average of EUR 1.370 billion or $17.9 \%$ of Bosnia and Herzegovina total imports. Table 1. shows that exports of agricultural and food commodities increased steadily in period of time $2008-2013$, and in 2013 were 1.6 times as high as in 2008. The coverage of imports by exports of agro-food commodities recorded growth in observed period; it increased from $16.45 \%$ in 2008 to $29.35 \%$ in 2015. Bosnia and Herzegovina in agro-food products trades mostly with CEFTA and EU countries (table 2).

In the study period, Bosnia and Herzegovina's trade of agricultural products to CEFTA countries amounted an average of EUR 771 million, or $30.0 \%$ of total country's export to CEFTA. Total export of agricultural products to CEFTA countries represented an average of EUR 175 million or $17.2 \%$ of Bosnia and Herzegovina's total exports to CEFTA countries and recorded increasing in period of time 2008 - 2012. The import of agro-food products from CEFTA countries had continuously increasing tendency in period of time 2008 -2011. The last four year of observed period recorded decreasing of import of agro - food products CEFTA countries. Agricultural imports amounted an average EUR 596 million or 38.8\% of total Bosnia and Herzegovina's import from CEFTA countries. The coverage of imports by exports of agro-food commodities recorded significant growth until 2013 ; it increased from $22.22 \%$ in 2008 to $36.36 \%$ in 2013 and were 1.6 times high as in the beginning of observed period. EU countries are the second most important trade partner of Bosnia and Herzegovina. On average about EUR 688 million in trade with agricultural products refer to EU countries (or $10.5 \%$ of total Bosnia and Herzegovina's trade with EU). Total exports from the agricultural sector to EU countries in study period represented an average of EUR 102 million, accounting for $4.03 \%$ of Bosnia and Herzegovina's total exports to this trade group. Agricultural imports from EU countries to Bosnia and Herzegovina had a increasing tendency. In observed period imports of agricultural products from EU countries reached an average of EUR 586 million, representing $14.4 \%$ of total Bosnia and Herzegovinas import. The coverage of imports by exports of agro-food products in trade between Bosnia and Heryegovina and EU countries recorded growth until 2012; it increased from $9.36 \%$ in 2008 to more than twice in 2012, when it reached $23.84 \%$.

In the structure of total exports for agro-food products in period of time $2008-2015$, the greatest share included the group of dairy products (tariff group 04), animal or vegetable fats and oils (tariff group 15), sugars and sugar confectionery (tariff group 17), edible fruit and nuts; peel of citrus fruits or melons (tariff group 08), preparations of meat, of fish or of crustaceanes, mollusks or other aqautic invertebrates (tariff group 16) and preparations of cereals, flour, starch or milk; pastry cook's products (tariff group 19) ( Figure 1.). The tariff groups 17 (sugars and sugar confectionery) and 15 (animal or vegetable fats and oils) are re-exported, not produced (sugar beet) or produced in modest amounts (oilseeds) in Bosnia and Herzegovina (Bajramović, Ognjenović, Butković, 2016). The average shares of main export agro-food products throughout the observed period were for dairy products $12.8 \%$, edible fruits and nuts $8.30 \%$, meat preparations $7.35 \%$ and preparations of cereals $8.07 \%$. The greatest share in the import structure of agricultural and food commodities (Figure 2.) was made up meat and edible meat offal (tariff group 02), cereals (tariff group 10), sugars and sugar confectionery (tariff group 17), miscellaneous edible preparations (tariff group 21), beverages, spirits and vinegar (tariff group 22) and residues and waste from the food industries; prepared animal fodder (tariff group 23). Beverages, spirits and vinegar recorded an average share of $11.9 \%$, cereals $8.32 \%$ and miscellaneous edible preparations $7.79 \%$ throughout analyzed period. 
Figure 1. Share (\%) of main commodity group of agro-food export Figure 2. Share (\%) of main commodity group of agro - food import
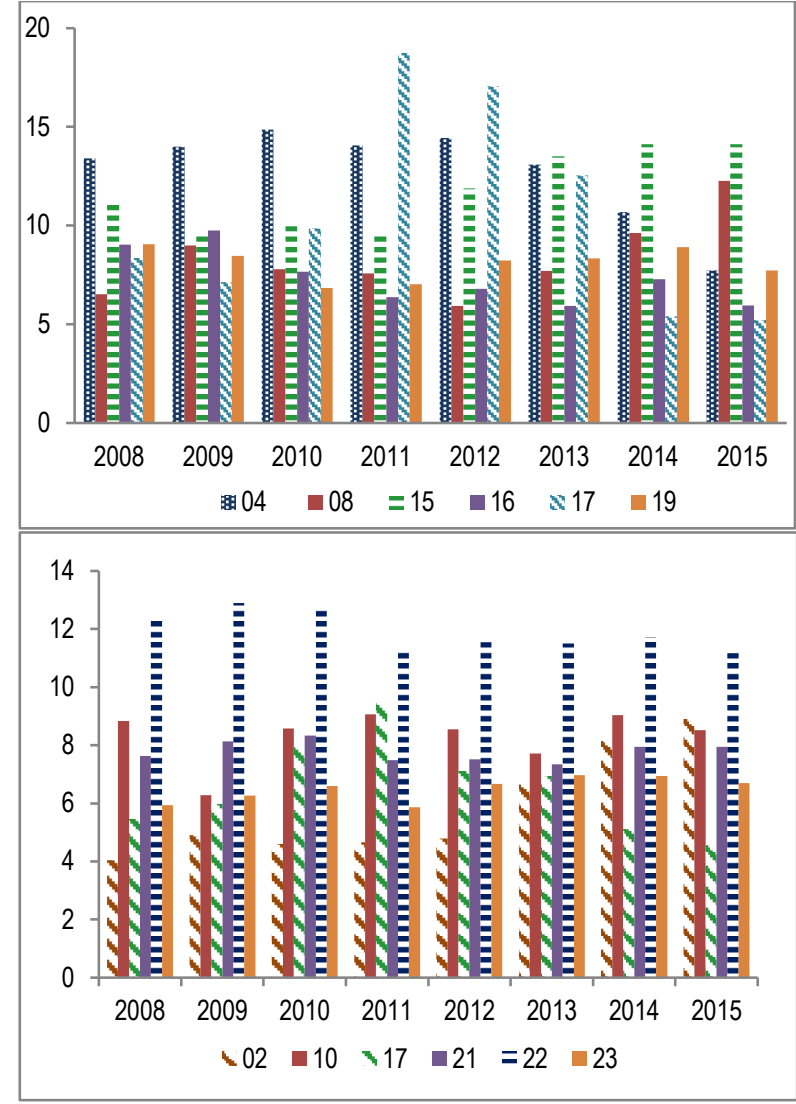

Source: Agricultural Statistics Database - Bosnia and Herzegovina 2016.

\section{Comparative advantages and intra - industry trade}

In order to define the position of agro - food sector of Bosnia and Herzegovina in relation to the international market, as well as to the markets of CEFTA and EU countries, are made analysis of comperative advantages and the level of specialization of intra-industry. By applaying the RCA indicator, agro-food sector of Bosnia and Herzegovina recorded lack of comparative advantages in total trade as well in trade with CEFTA and EU countries throughout period (Figure 3.). Less pronounced lack of comparative advantages of agro-food sector of Bosnia and Herzegovina was in trade with CEFTA countries, in compare with EU countries. In relation to EU countries, trade in agricultural and food comodities recorded the most pronounced lack of comparative advantages, especially in two last years of observed period. The values of GrubelLloyd's index for agro-food sector indicated the existing of the low level of specialization in intra - industry trade of Bosnia and Herzegovina, especially pronounced in trade with EU countries and total trade (Figure 4.). Based on values of GL indeks in trade with agricultural and food products between Bosnia and Herzegovina and CEFTA countries, it is visible the gradual growth of the level of specialization in intra-industry trade. In period 2012-2015 are recorded higher values of GL index in agricultural trade between Bosnia and Herzegovina and CEFTA countries; 53.68\% (2012); 53.33\% (2013); 50.37 
$\%(2014) ; 49.75 \%$ (2015). There are many factors that influence and determine the share of intra - industry trade in total trade of certain products between the countries. The hypothesis that major economies have a higher share of intra industry trade was confirmed through empirical researches and the thesis by Balassa and Bauwens (Balassa and Bauwens,1987). In according to Balassa and Bauwen's thesis, the intensity of intra - industry trade is positively correlated with the size of gross domestic product. In addition to this factor, the impact on the share of intra-industry trade in total trade have geographical distance between trading partners, inflow of foreign direct investment, trade liberalisation - free trade agreements,as well as EU integration process. Balassa and Bauwens (1987) believe that intra - industry trade is more intense if the trading partners are geographically closer. The correlation between foreign direct investment and the level of specialization in intra - industry trade can generally be considered positive, which is confirmed in researches of Greenaway at al. (1994). The great impact on intra-industry trade has trade liberalization. This is confirmed by studies that analyzed intra - industry trade between the EU and transition countries (Czech Republic, Hungary, Poland and Slovakia) for the periods 1993., 1997 and 2000, which showed a significant increasing of intra - industry trade in trade between EU and these countries. The reason for this is represented a combination of trade liberalization between EU and countries in transition process, through the implementation of trade agreements in 1992 (Gabrisch i Segnana, 2002). Also, the researches conducted by Aturpane, Djankov and Hoekman (1997) have confirmed, that the growth of intra - industry trade between EU and CEECs after the collapse of centrally planned economy, was driven through the market liberalization, changes in management and market structures, as well as the acceptance of new technologies.

Figure 3. Values of Balassa index of agro-food sector of BH

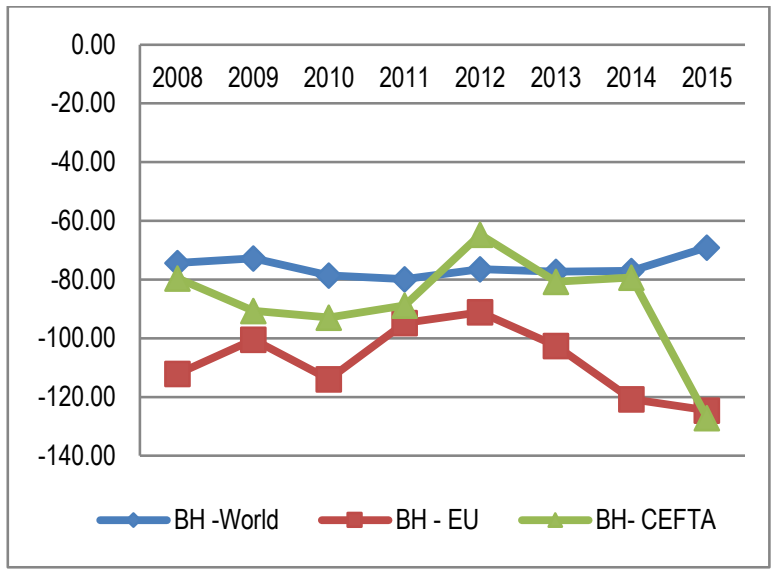

Figure 4. Values of Grubbel Lloyd index of agro-food sector of $\mathrm{BH}$

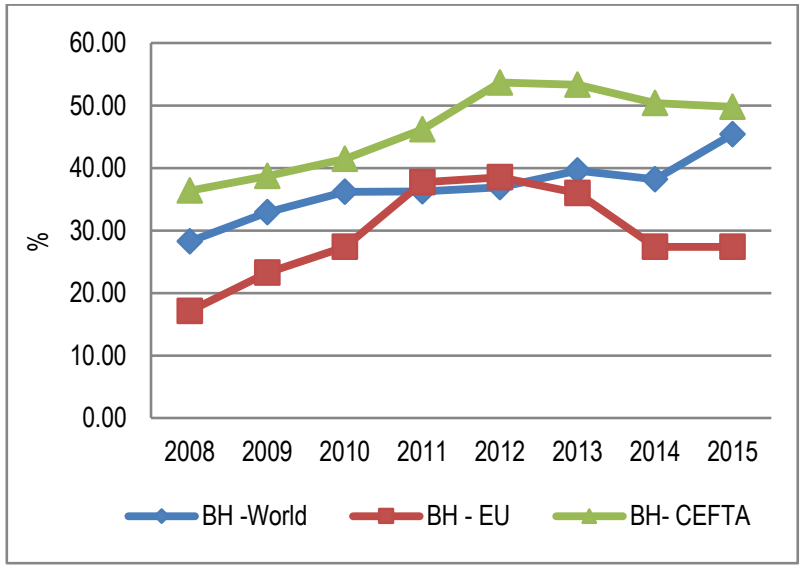


Source: Authors based on Agricultural Statistics Database - Bosnia and Herzegovina, 2016.

By applying of $k$ - means method, the values of RCA indicator, GL index and RUV indicator are used as variables. The results of clustering indicated the existence of three different clusters of product groups relative to the values of the analyzed RCA and GL index. The first step consisted in calculation of the unweighted arithmetic average of the two variables, wich are used as a basis for clustering. In according to number of product groups, the bigest is cluster 1 with 13 product groups. Cluster 3 contains 6 product groups and the smallest cluster is cluster 2 with 5 product groups. By comparing of the mean values of variables (RCA and GL index), it is evident that to cluster 1 belong the product groups with the most pronounced lack of comparative advantages and is prevalent of high level of specialization in inter-industry trade. A significant impact on the obtained values of cluster 1 have live animals, meat and edible meat offfal, cereals, products of milling industry. Product groups in cluster 2 have not comparative advantages, but they show high level of specialization in intra - industry trade in compare to cluster 1 . In this cluster are classified products of animal origin, vegetable plaiting materials, preparations of cerals and preparations of vegetables and fruits. Cluster 3 has the most less pronounced lack of comparative advantages, and the highest level of specialization in intra - industry trade, and includes dairy product groups, fish and crustaceans, edible vegetables and fruits, animal or vegetable fats and oils, preparations of meat. Table 3. shows the number of product groups in each cluster as well as mean values for the RCA indicator and the RUV indicator for generated clusters.

Table 3. The number of product groups in clusters and final cluster centers

\begin{tabular}{|l|l|l|l|}
\hline & Cluster 1 & Cluster 2 & Cluster 3 \\
\hline Number of products group & 13 & 5 & 6 \\
\hline RCA clusters centers & -.51 & -.29 & -.16 \\
\hline GL clusters centers &, 18 &, 47 &, 64 \\
\hline
\end{tabular}

Source: Calculated by the authors in SPSS.

Table 4. ANOVA - RCA indicator and GL index

\begin{tabular}{|l|l|l|l|l|l|l|}
\hline & \multicolumn{2}{|l|}{ Cluster } & Error & & \\
\hline & Mean Square & df & Mean Square & df & F & Sig. \\
\hline RCA &, 272 & 2 & 0,06 & 21 & 42,770 &, 000 \\
\hline GL index &, 467 & 2 & 0,03 & 21 & 138,328 &, 000 \\
\hline
\end{tabular}

Source: Calculated by the authors in SPSS.

ANOVA procedures show, that considering the $p$-value $(<0,01)$, there is significant differences among three existing clusters (table 4.).

The results of the $k$ - means cluster analysis indicated that agro - food sector of Bosnia and Herzegovina had five different clusters of product groups related to the relative unit values (table 5). The first step consisted in calculation of the unweighted arithmetic average of one variable - RUV based on data for three years 2008;2011;2015, used as a basis for cluster method. Cluster 4 stands out as the bigest with respect to the number of products groups, and contains 52 . This cluster has vertical intra - industry trade, since that mean values of RUV indicator 0.72 , precisely it is dominant low quality exports in this homogenous product groups. In that case, Bosnia and Herzegovina recpect to products in cluster 4 has low quality export, mostly in non - processed tobacco, vegetables (cabbage, kohlrabi, cauliflower, salad), some dairy products (chesse and cottage cheese, eggs, poultry and bird eggs in shell), oil- cake and other solid residues resulting from the extraction of soya, miscellaneous edible preparations (extracts, essences and concentrates), preparations of vegetables, fruits, nuts, preparations of cereals (bread, pastry, cakes), sugar and sugar confectionary, animal or vegetable fats. Cluster 3 contains 43 product groups. Vertical intra- industry specialization is dominant for this product groups, precisely high quality export. Typical products in Bosnia and Herzegovina trade patterns that have high quality exports are: fish, vegetables (tomatos, onions, cucumber, leguminous vegetables), fruits (fresh or dried grapes, apples, pears, melon, apricote, cherries, peaches, plums). Clusters 1,5 and 2 consist 15 products with predominant high quality vertical intra - industry trade, with cluster centers: 3.82 (Cluster 1); 6,22 (Cluster 5) and 8,76 (Cluster 2). The products of these clusters are fish fillets and other fish meat, some fruits (raspberries,blackberries and mulbery), vegetables (carrots, beets and other fresh, chilled or frozen vegetables).

Table 5. The number of products groups in clusters and final clusters centers 


\begin{tabular}{|l|l|l|l|l|l|}
\hline & Cluster 1 & Cluster 2 & Cluster 3 & Cluster 4 & Cluster 5 \\
\hline Number of products group & 10 & 3 & 43 & 52 & 2 \\
\hline RUV clusters centers & 3,82 & 8,76 & 1,59 &, 72 & 6,22 \\
\hline
\end{tabular}

Source: Calculated by the authors in SPSS.

ANOVA procedures show, that considering the $p$-value $(<0,01)$, there is significant differences among five existing clusters (table 6.).

Table 6. ANOVA - RUV indicator

\begin{tabular}{|l|l|l|l|l|l|l|}
\hline \multicolumn{2}{|l|}{ Cluster } & Error & & \\
\hline & Mean Square & df & Mean Square & df & F & Sig. \\
\hline RUV & 71,308 & 4 &, 118 & 105 & 603,926 &, 000 \\
\hline
\end{tabular}

Source: Calculated by the authors in SPSS.

The empirical results based on clustering showed that with exception of products groups in clusters 1,2 and 5 , low quality exports are dominant in Bosnia and Herzegovina's intra - industry trade.

\section{Conclusion}

Bosnia and Herzegovina had an unfavourable trade balance in agro - food sector, whereby export of the agricultural sector represented an average of EUR 311 million, or contributing the $7.9 \%$ of total country's export. Agricultural imports a mounted to an average of EUR 1.370 billion or $17.9 \%$ of Bosnia and Herzegovina total imports. Generally, calculated values of RCA indicator and GLI index for agro - food sector of Bosnia and Herzegovina indicated the lack of comparative advantages and low level of specialization in intra - industry trade. Between Bosnia and Herzegovina and CEFTA countries is recorded more intense intra-industry trade, especialy during the four last years of observed period (2012-2015), whereby the values of GL index are more than $50 \%$. The $k$ - means cluster analysis showed that in Bosnia and Herzegovina exist three clusters of product groups relative to comparative advantages and level of specialization in intra - industry trade. Cluster 1 has the most pronounced lack of comparative advantages and high level of specialization in inter - industry trade. $\mathrm{K}$ - means cluster analysis indicated that the agricultural and food sector in Bosnia and Herzegovina generated 5 clusters of product groups relative to ratio between unit value of export and unit value of import. Cluster 4 consisted 52 products group with prevailing low quality vertical intra - industry trade (low price export). Product groups in cluster 3 had high quality exports compared to cluster 4 . Three clusters; 1,2 , and 5 consisted the products groups with predominant high quality vertical intra - industry trade. In order to improve of position of agro - food sector and to achieve better integration and competitiveness in international trade, in Bosnia and Herzegovina is important to create the conditions related to improving of productivity agro - food sector, stronger support to the modernization of agricultural and food sector, attracting of foreign direct investments in agro - food sectors, as well as empowering of state institutions which have to provide the services to satisfy of customers requests (quality and safety assurance system).

\section{References}

[1] Abd - el - Rahman, K., (1991): Firm's Competitive and National Comparative Advantages as Joint Determinants of Trade Composition. Weltwirtschaftliches Archiv, 127 (1): 83-97.

[2] Algieri, B., (2004): Trade Specialization Patterns:The Case of Russia, BOFIT Discussion Papers No.19/2004, (Helsinki: BOFIT Institute).

[3] Agriculture in the Western Balkan countries, edited by Tina Volk. Studies on the Agricultural and Food Sector in Central and Eastern Europe. Chapter 3. Review of Agriculture and Agricultural Policy in Bosnia and Herzegovina by Sabahudin Bajramović, Dragana Ognjenović, Aleksandra Nikolić, IAMO 2010.

[4] Aturupane C., Djankov S., Hoekman B. (1997): Determinants of Intra - Industry Trade between East and West Europe, World Bank Policy Research Working Paper No.1850, Washington - World Bank.

[5] Aturupane, C., S. Djankov, and B. Hoekman. 1999. "Determinants of Intra-Industry Trade Between East and West Europe." Weltwirtschaftliches Archiv 135(1): 60-81.

[6] Analysis of the agricultural and rural development policies of the Western Balkan countries. 3. Bosnia and Herzegovina:agricultural policy brief, Sabahudin Bajramović, Dragana Ognjenović, Jakub Butković, JRC, Technical Reports 2016. 
[7] Balassa, B. (1965): Trade Liberalization and Revealed Comparative Advantage, The Manchester School of Economic and Social Studies, Vol.32, pp.99-123.

[8] Balassa, B., Bauwens, L. (1987): Intra - industry specialization in a multi - country and multi-industry framework. Economic Journal, br. 97.

[9] Blanes, Jose V., and Carmela Martin. 2000. "The Nature and Causes of Intra-Industry Trade: Back to the Comparative Advantage Explanation? The Case of Spain,. Weltwirtschaftliches Archiv 136(3): 423-441.

[10] Buturac G., Rajh E., (2006):Vertical Specialization and Intra - industry trade: The Case of Croatia.Economic Research, 19 (1):37-49.

[11] Falvey, R.(1981): Commercial Policy and Intra - Industry Trade, Journal of International Economics, 11(4):133134.

[12] Gabrisch H., Maria Luigia Segnana (2002): Why is trade between the European Union and the Transition economies vertical ?, Discussion Paper No.7.

[13] Grubel, H., Lloyd P., (1978), Intra - industry Trade: The Theory and Measurement of International Trade in Differentiated Products, (London:Macmillan).

[14] Greenway, D., R.C. Hine, and C. R. Milner. 1994. "Country-Specific Factors and the Pattern of Horizontal and Vertical Intra-Industry Trade in the U.K." Weltwirtschaftliches Archiv 130(1): 77-100. Greenaway, D., R.C. Hine, and C. R. Milner. 1995. "Vertical and Horizontal Intra-Industry Trade: A Cross-Industry Analysis for the United Kingdom." Economic Journal 105: 1505-1518.

[15] Greenaway, D., R.C. Hine, and C. R. Milner. 1995. "Vertical and Horizontal Intra-Industry Trade: A CrossIndustry Analysis for the United Kingdom." Economic Journal 105: 1505-1518

[16] [16] Helpman E., (1981): International Trade in the presence of product differentiation, economies of scale, and monopolistic competition: a Chamberlain - Heckscher - Ohlin approach, Journal of International Economies, 11 (3): 305-340.

[17] Krugman, P. R. (1981), Intra-Industry Specialization and the Gains form Trade. Journal of Political Economy, vol. 89, br. 5, pages 959-973.

[18] Lancaster, K. (1980), Intra-industry trade under Perfect Monopolistic Competition.Journal of International Economics, br. 10, pages 151-175.

[19] Reganati, F., Pittiglio R., (2005): Vertical Intra - Industry Trade: Patterns and Determinants in the Italian Case. Quaderni DSEMS 06-2005, (Foggia: Department of Economics, Mathematics and Statistics, University of Foggia).

[20] Vollrath, T.L (1991): A Theoretical Evaluation of Alternative Trade Intensity Measures of Revealed Comparative Advantage", Weltwirtschaftliches Archiv, 130 (2): 265- 279. 